Ankara Üniversitesi

SBF Dergisi,

Cilt 73, No. 4, 2018, s. 1141 - 1168

\title{
THE IMPACTS OF DIVERSIFICATION STRATEGIES OF TURKISH BANKS ON THEIR PROFITABILITY AND RISK: A PANEL DATA ANALYSIS
}

\author{
Doç. Dr. Yetkin Ģmar \\ Ankara Üniversitesi \\ Siyasal Bilgiler Fakültesi \\ ORCID: 0000-0002-4710-0346
}

\author{
Arş. Gör. Gökçe Gürsel \\ Ankara Üniversitesi \\ Siyasal Bilgiler Fakültesi \\ ORCID: 0000-0002-1855-3944
}

\author{
Dr. Sevgi Eda Tuzcu \\ Ankara Üniversitesi \\ Siyasal Bilgiler Fakültesi \\ ORCID: 0000-0002-3658-2546
}

\begin{abstract}
This paper empirically analyzes the effects of product (loan), sector and income diversification strategies on the performances and risks of Turkish commercial banks over the period 2005-2016, in which 2008-2009 treated as a crisis period. Profitability is measured by Return on Assets ratio and natural logarithm of Non-performing Loans is used as a proxy of risk. We evaluate the different dimensions of diversification and using the Entropy methodology to distinguish the total diversification into related and unrelated components. Diversification is captured in three broadly defined dimensions: incomes, products and sectors. Then, we associate all dimensions of diversification with bank profitability and risk measures, across banks and in years, via panel data analyses. In this way, the paper aims to provide recent evidence for Turkish banking sector's diversification strategies and their outcomes. Our findings indicate that, to be especially dominant on the within groups, income and product (loan) diversification increase return on assets while decreasing loan losses; sectoral diversification decreases profits, but increases risk.
\end{abstract}

Keywords: Diversification, Bank Performance, Bank Risk, Entropy Method, Panel Data Analysis

Türk Bankalarının Çeşitlendirme Stratejilerinin Kârlılık ve Riskleri Üzerindeki Etkileri: Panel Veri Analizi

\section{Öz}

Bu makale; 2005-2016 döneminde Türkiye bankacıllk sektöründe faaliyet göstermekte olan mevduat bankalarının gelir, ürün (kredi) ve sektör üzerindeki çeşitlendirme eğilimlerini ortaya koymakta ve aynı zamanda bu stratejilerin bankaların karlılık ve riskleri üzerindeki etkilerini ölçmektedir. Analiz dönemi içerisinde yer alan 2008-2009 yılları kriz dönemi olarak ele alınmış ve bir kontrol değişkeni olarak kabul edilmiştir. Performans veya karlılık, kar / varlıklar oranı ile ölçülürken, riskin bir göstergesi olarak ise sorunlu kredilerin doğal logaritması kullanılmıştır. Çalışma, çeşitlendirme ölçütünü Entropi adı verilen bir yöntemle grup içi ve gruplar arası bileșenlerine ayırarak ve Türk bankacılık sektörünün son dönem çeşitlendirme stratejilerinin sektör karlılığı ve riski üzerindeki etkilerini ortaya koyarakilgili yazına katkıda bulunmaktadır. Elde edilen bulgulardan, özellikle grup içi bileșeninde baskın olmak üzere, gelir ve ürün çeşitlendirmesinin karlılığı arttırıp riski azalttığı; sektör çeşitlendirmesinin ise tersine karlılığı azaltıp riski arttırdığı sonuçlarına ulaşıııııștır. Analizi

Anahtar Sözcükler: Çeşitlendirme, Banka Performansı, Banka Riski, Entropi Modeli, Panel Veri

* Makale geliş tarihi: 30.05.2018

Makale kabul tarihi: 24.09.2018 


\section{The Impacts of Diversification Strategies of Turkish Banks on their Profitability and Risk: A Panel Data Analysis*}

\section{Introduction}

A deep financial crisis in the years 2000 and 2001 affected the Turkish economy especially the banking sector in Turkey. In these years, all indicators of the banking sector worsened. After overcoming that crisis, most of the indicators grew by over more than two times in the five years period between 2003 and 2008. These positive developments were due to the favorable domestic and international macroeconomic situation, concurrently with the "restructuring processes" on the banking sector, which is called as "Banking Restructuring Program" and started in May 2001.

Between the years 2005 and 2016, which is also selected as the analysis period in this study, Turkish financial system totally recovered from the effects of 2000-2001 crises and it can be generally characterized by falling interest rates, low inflation and capital inflow, in parallel with the rising economic activity.

However, within this period, besides short-term global fluctuations in the financial markets observed in 2006, beginning from 2007, global developments led to a rapid contraction in the world economy and more substantial fluctuations in financial markets. Starting from the second quarter of 2008, in particular, the global issues have had considerable reflections in Turkey, i.e. decreased the domestic and external demand. External financing became more limited and the public sector borrowing requirement increased. Assets, deposits and non-performing loans totally worsened by the end of 2008. Although the effects of 2008-2009 crisis are present in the major indicators like profitability of the banking system at that time, strong banking regulations prevented another sharp decline and the crisis did not worsen. As a result, Turkish banking system had exhibited a relatively stable outlook. In other words, the

* A preliminary version of this study was presented at the Russian Economic Congress in Suzdal, Russian Federation (17th - 21th of February 2013). 
global crisis had not dramatically affected the performance of the Turkish banks, in contrast to the fact that it had caused substantial negative effects on the performances of the most the European and the US banks. Therefore, Turkish banking sector has become more attractive for foreign investors.

In the recent years, by the end of 2016, the effects of 2008-2009 global crisis has passed, the Turkish Banking System maintained a stable growth, and the total assets increased steadily. However, nonperforming loans to total assets ratio have been increasing since 2012-2013 (see Figure 6. in Chapter 4). In short, while Turkish banking system enjoys a growth period, its risk is also increasing in terms of nonperforming loans.

On the other side, this growth period in banking sector and the effects of fluctuations decreased profit margins and caused more competitive pressure for the banks. It means that the recent developments have forced banks to account for expenses and loan losses while increasing their loan supply to become more profitable. Also, there are findings which indicate that non-interest revenues earned from diversified financial services have a crucial role in bank performance in Turkish banking sector in this period (Çınar, 2011; BRSA Reports, 2010, 2011). Therefore, detecting in which way the performance and risk are affected by diversification in loan portfolio composition or income sources of banks became more important. In other words, there is a need to examine the role of diversification in this history of success for Turkish banking system. In this context, this study provides an analysis on the Turkish commercial banks with respect to their income, loan and sectoral portfolio diversification strategies and their impacts on bank performance and risk.

However, as it will be explained in detail in the following chapter of this study, the empirical findings of the related literature assert that diversification of bank's assets (or incomes) does not guarantee to produce superior performance and/or greater safety for banks (e.g. see Acharya, et al. 2006). The aim of this paper is to evaluate different dimensions of diversification and associate the results with the bank performance measures in order to provide recent evidence from Turkish banking sector.

For this aim, in this paper, diversification is captured in three broadly defined dimensions: incomes and loans (products) and sectors. All dimensions are measured in related and unrelated components by using the Entropy methodology proposed by Palepu (1985). Then, all dimensions of diversification are associated with profitability and risk measures, by using appropriate panel data analysis methods. The paper empirically analyzes the effects of loan and income diversification strategies on the performances of a selected sample of Turkish commercial banks over the period 2005-2016. 
The rest of the paper is organized as follows. Chapter 1 provides a literature review. In Chapter 2, formal methodology is introduced and the main scope and the general formulation of this research are explained. Chapter 3 introduces data used in this study and Chapter 4 presents the results of the empirical application. The last chapter concludes the paper.

\section{Literature Review: Diversification and Bank Performance}

Diversification can be defined as the expansion of credit lines to new sectors, or borrowers or geographical regions etc. in order to preserve from risk of default or in order to find new profitable areas. There are some reasons that bank management should take into account for diversification of assets and their income.

First of all, there are regulatory and supervisory issues supporting diversification in the bank loan portfolios and asset choices in many countries because of their potential impacts on macro economy. There are also arguments for limiting a bank's exposure of its loans to a single borrower in Basel II Accords (Basel Committee of Banking Supervision, 1991).

Second, there are theoretical assertions supporting diversification. According to traditional banking theory (Diamond, 1984), banks should diversify their loan portfolio in order to reduce financial information costs incurring due to asymmetric information. On the other hand, there are empirical findings as well as theoretical assertion which supports the idea that diversification is harmful in some cases. According to the corporate finance theory, banks should focus on specific sectors or group of sector in order to take benefits of expertise in these sectors (Tabak et al., 2011).

There are also empirical findings showing that diversification is beneficial for reducing risk in the loan portfolio and / or for earning higher profits. Especially for the high-risk portfolios, this effect is more expectable (Winton, 1999). Furthermore, during the crisis periods, it has a preservation effect against banks' probability of default. On the contrary, there is also substantial amount of empirical evidence which shows that diversification increases the risk and reduces the performances of banks (Acharya et al., 2006, Berger et al., 2010; Hayden et al., 2007). Therefore, diversification is a difficult decision for bank management, and it is always a valuable effort to investigate the effects of different types of diversification on performances of banks in different periods and different regions.

The relationship between diversification and performance, and diversification and risk have been analyzed by Acharya et al. (2006) in Italy; 
Meyer and Yeager (2001) and Stiroh and Rumble (2006) in the US, Mercieca et al. (2007) and Beale et al. (2007) in the Europe, Hayden et al. (2007) and Kamp et al. (2007) in Germany, Baele et al. (2007) and Berger et al. (2010) in China, and Tabak et al. (2011) in Brazil, separately for economic sector and asset decompositions and/or geographical focus and/or sources of income.

More detailed literature review is provided by using Table 1. Below, Table 1 summarizes the studies in the related literature.

Table 1. Selected Studies from the Literature

\begin{tabular}{|c|c|c|c|c|c|}
\hline Authors & $\begin{array}{l}\text { Sample } \\
\text { Period }\end{array}$ & Sample Banks & $\begin{array}{c}\text { Types of } \\
\text { Diversification }\end{array}$ & $\begin{array}{l}\text { Dependent } \\
\text { Variables }\end{array}$ & Conclusion \\
\hline $\begin{array}{l}\text { Zhou } \\
(2014)\end{array}$ & $\begin{array}{l}1997- \\
2012\end{array}$ & $\begin{array}{l}62 \text { Chinese } \\
\text { commercial } \\
\text { banks }\end{array}$ & $\begin{array}{c}\text { Income } \\
\text { diversification }\end{array}$ & Bank risk & $\begin{array}{l}\text { Income diversification } \\
\text { is not statistically } \\
\text { significant and thus } \\
\text { does not reduce banks' } \\
\text { overall risk. }\end{array}$ \\
\hline $\begin{array}{l}\text { Meslier et. } \\
\text { Al. (2014) }\end{array}$ & $\begin{array}{l}1999- \\
2005\end{array}$ & $\begin{array}{l}39 \text { Philippines } \\
\text { universal and } \\
\text { commercial } \\
\text { banks }\end{array}$ & $\begin{array}{c}\text { Income } \\
\text { diversification }\end{array}$ & Bank return & $\begin{array}{l}\text { Income diversification } \\
\text { increases banks' } \\
\text { return. }\end{array}$ \\
\hline $\begin{array}{l}\text { Swada } \\
(2013)\end{array}$ & $\begin{array}{l}1999- \\
2001\end{array}$ & $\begin{array}{l}113 \text { Japanese } \\
\text { banks }\end{array}$ & $\begin{array}{c}\text { Income } \\
\text { diversification }\end{array}$ & $\begin{array}{l}\text { Stock based } \\
\text { bank risk and } \\
\text { return }\end{array}$ & $\begin{array}{l}\text { Income diversification } \\
\text { increases banks' } \\
\text { market value. There } \\
\text { are not any strong } \\
\text { evidence suggesting } \\
\text { income diversification } \\
\text { reduces banks' risk. }\end{array}$ \\
\hline $\begin{array}{l}\text { Lee et. al. } \\
\text { (2014) }\end{array}$ & $\begin{array}{l}1995- \\
2009\end{array}$ & $\begin{array}{l}22 \text { countries in } \\
\text { Asia - } 967 \\
\text { individual banks }\end{array}$ & $\begin{array}{c}\text { Income } \\
\text { diversification }\end{array}$ & $\begin{array}{l}\text { Bank return } \\
\text { and risk }\end{array}$ & $\begin{array}{l}\text { Non interest activities } \\
\text { reduces banks' risk but } \\
\text { does not increase their } \\
\text { return. }\end{array}$ \\
\hline $\begin{array}{l}\text { Hayden et. } \\
\text { Al. (2007) }\end{array}$ & $\begin{array}{l}1996- \\
2002\end{array}$ & $\begin{array}{l}983 \text { German } \\
\text { banks }\end{array}$ & $\begin{array}{l}\text { Product, sector and } \\
\text { geographical } \\
\text { diversification }\end{array}$ & Bank return & $\begin{array}{l}\text { Diversification } \\
\text { reduces banks' return. }\end{array}$ \\
\hline $\begin{array}{l}\text { Baele et. } \\
\text { al. (2007) }\end{array}$ & $\begin{array}{l}1989- \\
2004\end{array}$ & $\begin{array}{c}17 \text { European } \\
\text { countries - } 143 \\
\text { banks }\end{array}$ & $\begin{array}{c}\text { Income } \\
\text { diversification }\end{array}$ & Bank value & $\begin{array}{c}\text { Income diversification } \\
\text { increases banks' value } \\
\text { and decreases their } \\
\text { risk }\end{array}$ \\
\hline $\begin{array}{l}\text { Mercieca } \\
\text { et. al. } \\
\text { (2007) }\end{array}$ & $\begin{array}{l}1997- \\
2003\end{array}$ & $\begin{array}{l}755 \text { small } \\
\text { European banks }\end{array}$ & $\begin{array}{c}\text { Income } \\
\text { diversification }\end{array}$ & Bank return & $\begin{array}{l}\text { Income diversification } \\
\text { reduces bank } \\
\text { performance. }\end{array}$ \\
\hline
\end{tabular}




\begin{tabular}{|c|c|c|c|c|c|}
\hline $\begin{array}{l}\text { Elsas et. al. } \\
\quad(2010)\end{array}$ & $\begin{array}{l}1996- \\
2008\end{array}$ & $\begin{array}{c}9 \text { European } \\
\text { countries - } 380 \\
\text { banks }\end{array}$ & $\begin{array}{c}\text { Income } \\
\text { diversification }\end{array}$ & $\begin{array}{l}\text { Bank value } \\
\text { and } \\
\text { profitability }\end{array}$ & $\begin{array}{c}\text { Income diversification } \\
\text { increases bank } \\
\text { profitability and } \\
\text { market value }\end{array}$ \\
\hline $\begin{array}{l}\text { Berger et. } \\
\text { al. (2010) }\end{array}$ & $\begin{array}{l}1996- \\
2006\end{array}$ & $\begin{array}{l}88 \text { Chinese } \\
\text { banks }\end{array}$ & $\begin{array}{l}\text { Loans, deposits, } \\
\text { assets and } \\
\text { geographical } \\
\text { diversification }\end{array}$ & $\begin{array}{l}\text { Bank return } \\
\text { and expenses }\end{array}$ & $\begin{array}{l}\text { Diversification } \\
\text { increases cost and } \\
\text { reduces profitability. }\end{array}$ \\
\hline $\begin{array}{l}\text { Lee et. al. } \\
\text { (2012) }\end{array}$ & $\begin{array}{l}2002- \\
2010\end{array}$ & $\begin{array}{c}17 \text { European } \\
\text { countries - } 710 \\
\text { banks }\end{array}$ & $\begin{array}{c}\text { Income } \\
\text { diversification }\end{array}$ & Bank return & $\begin{array}{l}\text { Diversification } \\
\text { reduces return for high } \\
\text { performance banks but } \\
\text { for low performance } \\
\text { banks diversification } \\
\text { increases return. }\end{array}$ \\
\hline $\begin{array}{l}\text { Stiroh and } \\
\text { Rumble } \\
(2006)\end{array}$ & $\begin{array}{l}1997- \\
2002\end{array}$ & $\begin{array}{c}\text { U.S. Bank and } \\
\text { financial holding } \\
\text { companies }\end{array}$ & $\begin{array}{c}\text { Income } \\
\text { diversification }\end{array}$ & Bank return & $\begin{array}{c}\text { Diversification } \\
\text { increases bank return. }\end{array}$ \\
\hline $\begin{array}{l}\text { Acharya } \\
\text { et. al. } \\
(2006)\end{array}$ & $\begin{array}{c}1993- \\
1999\end{array}$ & Italian banks & $\begin{array}{l}\text { Broad asset sector } \\
\text { and economic sector } \\
\text { diversification }\end{array}$ & $\begin{array}{l}\text { Bank risk and } \\
\text { return }\end{array}$ & $\begin{array}{c}\text { Diversification } \\
\text { increases bank return. } \\
\text { There is a U shaped } \\
\text { bank diversification } \\
\text { vs. bank return } \\
\text { relationship is } \\
\text { observed. }\end{array}$ \\
\hline $\begin{array}{l}\text { Tabak et. } \\
\text { al. }(2006)\end{array}$ & $\begin{array}{l}2003- \\
2009\end{array}$ & $\begin{array}{l}96 \text { Brazilian } \\
\text { commercial } \\
\text { banks }\end{array}$ & $\begin{array}{l}\text { Economic sector } \\
\text { diversification }\end{array}$ & $\begin{array}{l}\text { Bank risk and } \\
\text { return }\end{array}$ & $\begin{array}{l}\text { Diversification } \\
\text { increases bank risk } \\
\text { and reduces bank } \\
\text { return }\end{array}$ \\
\hline $\begin{array}{l}\text { Gurbuz et. } \\
\text { al. (2013) }\end{array}$ & $\begin{array}{l}2005- \\
2011\end{array}$ & $\begin{array}{l}26 \text { Turkish } \\
\text { banks }\end{array}$ & $\begin{array}{c}\text { Income } \\
\text { diversification }\end{array}$ & Bank return & $\begin{array}{c}\text { Diversification } \\
\text { increases bank return. }\end{array}$ \\
\hline
\end{tabular}

The diversification literature contains different countries, diversification measures, time periods and methodologies and the results are contradictory. Income diversification is generally measured by the proportion of non-interest income activities in total operating income. The studies employ different control variables like size, ownership structure and time dummies. Bank return or performance is generally measured by Return on Asset (ROA) or a risk adjusted version of ROA. Also, some studies use banks' market value as dependent variables.

Results from these studies are mixed. It seems that even with the robustness checks, there is not a clear trend stating the positive effect of diversification on bank return. For example, Mercieca et al. (2007: 1984) found that for small European banks income diversification reduces bank performance whereas Baele et.al. (2007: 2013) found income diversification increases bank value and bank risk. Furthermore, Elsas et al. (2010: 1280) showed that income 
diversification increases bank profitability and value. It is worthwhile to note that while these studies differ in sample, they chose similar time periods therefore, these banks operate similar macroeconomic environments which seem to not have a significant effect on results.

Another trend to observe from the literature is that in developed economies, the diversification generally has a positive effect on bank return whereas in developing economies, this effect either does not exist or is the opposite, i.e. diversification reduces bank return. Also, Tabak et al. (2006) note that in emerging economies, banks have more concentrated loan portfolios than developed economies' banks. Therefore, some of the differences in these findings stems from the differences in the economic outlook.

\section{Performance and Diversification in Turkish Banking: Data, Methodology and Application}

\subsection{Data and Variables}

As of 2016, there are 52 banks operating in the Turkish banking system. 34 of them are commercial banks. 3 banks are state owned, while in 21 of the commercial banks, more than $51 \%$ the shares are held by foreigners ( the Banks Association of Turkey, 2017). However, only 20 banks can be included into the analyses because of the following reasons: First, many of the banks that are not included into the dataset mainly have one or two branches in Turkey and they do not deal with the main banking activities. Others are too small to be analyzed or the data are not available for them within the entire sample period.

Although our sample consists of a relatively small number of banks (cross sections) when compared to the literature, these banks control $96.66 \%$ of the total bank assets by the end of the analysis period. The banks included in the analyses, their ownership structures and their shares in the banking sector by total assets at the end of 2016 are given in Table 2 .

Table 2. Banks Included into the Sample

\begin{tabular}{|c|c|c|}
\hline Banks & Ownership Structure & $\begin{array}{c}\text { Share in The Sector by } \\
\text { Total Assets (\%) }\end{array}$ \\
\hline Akbank T.A.Ş. & Turkish Private & $11.05 \%$ \\
\hline Alternatif Bank A.Ş. & Foreign & $0.67 \%$ \\
\hline Anadolubank A.Ş. & Turkish Private & $0.51 \%$ \\
\hline Burgan Bank A.Ş. & Foreign & $0.56 \%$ \\
\hline
\end{tabular}




\begin{tabular}{|c|c|c|}
\hline Citibank A.Ş. & Foreign & $0.33 \%$ \\
\hline Denizbank A.Ş. & Foreign & $4.21 \%$ \\
\hline QNB FinansBank A.Ş. & Foreign & $4.14 \%$ \\
\hline HSBC Bank A.Ş. & Foreign & $0.99 \%$ \\
\hline ING Bank A.Ş. & Foreign & $2.03 \%$ \\
\hline Şekerbank T.A.Ş. & Turkish Private & $0.97 \%$ \\
\hline ICBC Bank & Foreign & $0.34 \%$ \\
\hline Türk Ekonomi Bankası A.Ş. & Foreign & $3.25 \%$ \\
\hline Turkish Bank A.Ş. & Turkish Private & $0.06 \%$ \\
\hline Türkiye Cumhuriyeti Ziraat Bankası A.Ş. & State-owned & $14.59 \%$ \\
\hline Türkiye Garanti Bankası A.Ş. & Foreign & $11.59 \%$ \\
\hline Türkiye Halk Bankası A.Ş. & State-owned & $9.44 \%$ \\
\hline Türkiye İş Bankası A.Ş. & Turkish Private & $12.71 \%$ \\
\hline Türkiye Vakıflar Bankası T.A.O. & State-owned & $8.67 \%$ \\
\hline Turkland Bank A.Ş. & Foreign & $0.23 \%$ \\
\hline \multirow[t]{2}{*}{ Yapı ve Kredi Bankası A.Ş. } & Turkish Private & $10.31 \%$ \\
\hline & Total & $96.66 \%$ \\
\hline
\end{tabular}

Financial data for the banks are obtained from the database provided by the Banks Association of Turkey (BAT) and the Public Disclosure Platform. The detailed information about the annual financial positions, balance sheets and income statements of all banks in the sample are examined from these two databases. The sample period covers the years between 2005 and 2016. It is the most recent period for which the data is available for the sample. The annual unconsolidated accounting reports are used.

\subsection{Variables Used in the Analyses}

As mentioned before, the main goal of this paper is to show that the relation between the banks' diversification strategy and its performance, such as profitability and risk. This paper argues that bank performance depends on the degree or type of the diversification, that is to say diversification in interest and non-interest revenues, and diversification with respect to borrowers or financial products. In addition, diversification is split into two parts, namely related and 
unrelated diversification, in order to observe their own effects. To do so, regression analyses are conducted. First, the variables will be defined. Next, the general formulation of our empirical approach will be explained.

\section{Dependent Variables: Performance and Loan Risk}

Two separate dependent variables have been defined. Return on Assets $(R O A)$ is defined as the performance measure to understand whether diversification results in higher returns. For risk models, InNPL (Natural logarithm of Nonperforming Loans) is used as a proxy for banks' risk.

\section{Independent Variables: Diversification Measures}

Since this study investigates the effect of diversification on banks' performance, the main independent variables are the diversification measures obtained from the Entropy methodology. As it will be explained in the following chapter (Chapter 3) in formal terms, this methodology distinguishes the total diversification (TD) into its components, such as across groups diversification (AGD) and total within group diversification (TWGD). Entropy depends on hierarchical structures, so in this study, three hierarchical structures (or groupings) are constructed. These groupings are based on banks' loan exposures and sources of income. They lead us to define the related (within group) and unrelated (across groups) diversification components, which are defined and measured for each bank at a specific point of time. By doing so, we investigate the sensitivity of these different types and dimensions (levels) of diversification as well.

These groupings and detailed classifications in Turkey are given in Table 3.

Table 3. Diversification Strategies

\begin{tabular}{|c|c|}
\hline Diversification Strategy & Groups \\
\hline $\begin{array}{l}\text { Loan Diversification with respect to } \\
\text { Industries (Sectors) }\end{array}$ & 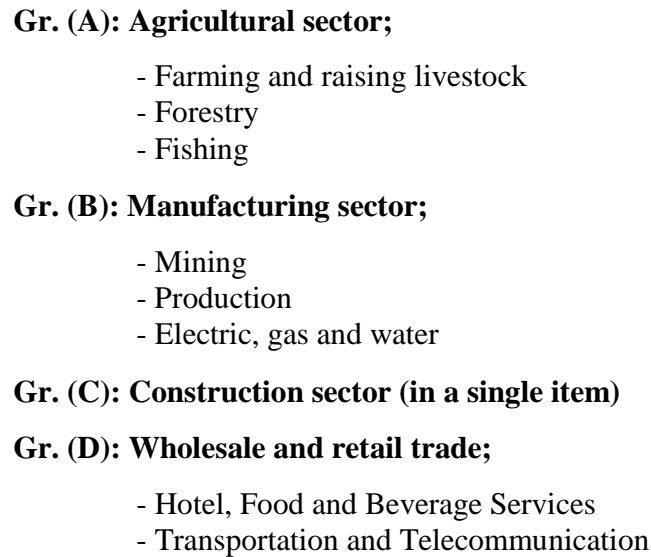 \\
\hline
\end{tabular}




\begin{tabular}{|l|c|}
\hline & - Financial Institutions \\
& - Real Estate and Rental Services \\
& - Self-Employment Services \\
& - Education Services \\
& - Health and Social Services in The \\
& Services Sector \\
& Gr. (E): Other sectors which are not classified \\
above (in a single item)
\end{tabular}

As it can be seen from these groupings in the Turkish Banking System, the main sectorial decomposition is as follows: Agricultural, Manufacturing, Construction, Services, and other sectors. Loan risk, on the other hand, is divided into two groups in terms of financial products, namely consumer loans, and commercial loans. Following these groupings, the loan portfolio diversification (concentration) is measured by identifying the individual bank loan exposures to different industries / sectors.

The other grouping is realized with respect to income diversification. Actually, it would be a better way to measure the income diversification according to the two main groups of banking activities; i.e. (i) income from traditional banking activities which includes activities related to lending, taking 
deposits and investment in securities and (ii) income from non-traditional banking activities, which are trading and security market services and fund management and insurance services (Vallascas et al., 2011; Chiorazzo, et al., 2008). However, due to the data limitations, we use interest based revenues and fee-based revenues. By using these different groupings, we are allowed to discuss the diversification from various dimensions. Hence, this approach provides us the capability of assessing the consequences of different diversification strategies in a closer view.

\section{Control Variables and Dummies}

While ROA and NPL are the dependent variables for two different analyses and the Entropy methodology is used for the diversification measures as independent variables, this study uses different control variables as well, as follows:

- Size: In order to observe whether size of a bank is important in the relation between diversification and risk or return, we use the natural logarithm of total assets in the analyses.

- Ownership Structure: Two different ownership dummies are employed to understand whether the ownership structure affects the diversification - risk and return relation. These are defined whether the bank is state owned or not, and more than $51 \%$ of its shares are held by foreigners.

- Macroeconomic Factors (Time Dummy): In order to capture the effects of recent mortgage crisis on the banking sector, a time dummy is added into the analyses for years 2008 and 2009.

- Interest Rate: Overnight interest rates of Central Bank of Turkey observed at the end of analysis years are used as interest rate.

- Total Loans/Total Assets: This variable is used as a proxy for banks' risk preference.

- Growth: Annual growth rate of total assets of banks.

The detailed variable definitions can be seen in the Appendix.

\subsection{Methodology}

In this chapter, formal methodology used in this study is introduced and the framework of the empirical research which is constructed in accordance with the concepts stated above is presented. 


\section{Diversification Measure and Its "Related" and "Unrelated"}

Components: Entropy Models

In this paper, diversification is measured by Entropy methodology to distinguish the total diversification into related and unrelated components. Entropy measure stems from the seminal work of Shannon (1948), used in informatics (Theil, 1967), adapted to measurement of diversification by Jacquemin and Berry (1979) and distinguished its components which are used to determine the related and unrelated product diversification components by Palepu (1985).

Entropy index distinguishes between diversification within groups which consist of highly-related components and diversification across these groups. ${ }^{1}$

Formally, Entropy measure can be defined as follows:

Let the amount of exposure of bank $b$ at time $t$ to each product (or the amount of each type of earning) $i$ denoted as $X_{i b t}$, where $(i=1 \ldots m)$. Then, relative amount of the exposure / earnings in total amount of loan exposure/earnings will be;

$$
P_{i b t}=\frac{X_{i b t}}{\sum_{i=1}^{m} X i b t}
$$

Then the total diversification of this bank, at the given point of time is measured by this equation, by the entropy measure:

$$
T D_{b t}=\sum_{i=1}^{m} P_{i b t} \operatorname{In}\left(\frac{1}{P_{i b t}}\right)
$$

Here, $\ln$ represents natural logarithm.

According to this measure, for different relative measures $\left(\mathrm{P}_{\mathrm{i}}{ }^{\prime} \mathrm{s}\right)$, lower $T D_{b t}$ is calculated. If $T D_{b t}$ is near to 0 then it means the loan portfolio of the bank is highly concentrated (low diversified). On the other side, if relative exposures are very close to each other, then $T D_{b t}$ takes higher values. At the extreme point, if they are near equal, then $T D_{b t}$ takes its highest value, which is $\mathrm{In}(\mathrm{m})$. It means perfect diversification.

Consider loan or earning types which have similar characteristics, for example, earnings from traditional banking activities, e.g. interest revenues

1 Herfindahl Hirschman Indices (HHI) were also calculated and used in the analyses, however since they have more than $98 \%$ correlation with total Entropy measures, they are not reported, but only used for the robustness checks. 
from loan exposures (rather than fee based revenues) or loans to consumers / households (rather than banks) and let $\mathrm{m}$ types of loan exposures or earnings can be distinguished to $\mathrm{n}$ groups, where $(\mathrm{j}=1, \ldots \mathrm{n})$ and $m \geq n$.

Then within any $j^{\text {th }}$ group, the diversification is measured by

$W G D_{b t}^{j}=\sum_{i \in j} P_{i b t}^{j} \operatorname{In}\left(\frac{1}{P_{i b t}^{j}}\right)$

which is called as "Within Group Diversification" or "Related Entropy" measure.

Here $P_{i b t}{ }^{j}$ shows the share of the exposure to the product $i$ in its group $j$, which is done by the bank $b$ at time $t$. Since the bank $b$ distributes its total exposures among $n$ groups, by taking into account the shares of the groups in total exposure "Total" Within Group Diversification is calculated as:

$T W G D_{b t}=\sum_{j=1}^{n} W G D_{b t}^{j} P_{b t}^{j}$

Here $P_{b t}{ }^{j}$ indicates the relative weights of each group in total.

Across Groups or Unrelated Diversification (AGD) measures the degree of diversification of loans between groups and shows all relative groups' shares in total. This component is computed as follows:

$A G D_{b t}=\sum_{j=1}^{n} P^{j} \operatorname{In}\left(\frac{1}{P^{j}}\right)$

Palepu (1985: 253) has shown that Total Diversification (TD) is the sum of its two components, i.e. Total Within Groups (Related) Diversification and Across Groups (Unrelated) Diversification:

$T D_{b t}=T W G D_{b t}+A G D_{b t}$

\section{Panel Data Analysis}

This study mainly follows the panel specification used by Acharya, et al. (2006) and Tabak, et al. (2011). First, we investigate the impact of diversification measures on bank return by running the following regression:

$$
\begin{aligned}
& \text { ROA }_{b, t}=\alpha_{0}+\alpha_{1} \text { AGD }_{b, t}+\alpha_{2} \text { TWGD }_{b, t}+\alpha_{3} \text { Size }_{b, t}+\alpha_{4} \text { OWn }_{1}+\alpha_{5} \text { Own }_{2}+ \\
& \alpha_{6} D_{\text {time }}+\alpha_{7} \text { Total Loans }_{\text {Total Assets }}+, t \\
& +\alpha_{8} \text { Growth }_{b, t}+\alpha_{9} \text { Interest }_{b, t}+\varepsilon_{b, t}(7)
\end{aligned}
$$


To measure the effects of Total Diversification (TD) on ROA, the following regressions are run.

ROA $_{b, t}=\alpha_{0}+\alpha_{1}$ TD $_{b, t}+\alpha_{2}$ Size $_{b, t}+\alpha_{3}$ Own $_{1}+\alpha_{4}$ Own $_{2}+\alpha_{5} D_{\text {time }}+$
$\alpha_{6}$ Total Loans $_{\text {Total Assets }_{b, t}}+\alpha_{7}$ Growth $_{b, t}+\alpha_{8}$ Interest $_{b, t}+\varepsilon_{b, t}$

For the estimation procedure, Tabak, Fazio, and Cajueiro (2011) recommend Feasible Generalized Least Squares (FGLS), since they have a high degree of group wise heteroscedasticity. In this study, our data set has a high degree of heteroscedasticity across error terms. As a result, Robust OLS estimations are employed and White heteroscedasticity consistent standard errors are reported.

Acharya, et al. (2006) and Tabak, et al. (2011) note that the relation between diversification and bank return can be a function of bank risk as well. In fact, bank risk may affect the bank's diversification policy in a non-linear way. As a result, the ratio of nonperforming loans to total loans $\left(\mathrm{NPL} \_ \text {percentage }=\mathrm{NPL} / \mathrm{Total} \text { Loans) and its square ([NPL_percentage }\right]^{2}=$ (NPL/Total Loans) $)^{2}$ ) are added into the previous equation. The new bank return - across groups and total within groups diversification relation becomes as follows:

$R O A_{b, t}=\alpha_{0}+\alpha_{1} A G D_{b, t}+\alpha_{2} T W G D_{b, t}+\alpha_{3} \operatorname{Size}_{b, t}+\alpha_{4} O w n_{1}+\alpha_{5} O w n_{2}+$ $\alpha_{6} D_{\text {time }}+\alpha_{7}$ Total Loans $_{\text {Total Assets }_{b, t}}+\alpha_{8}$ Growth $_{b, t}+\alpha_{9}$ Interest $_{b, t}+$ $\alpha_{9} T D_{b, t} * N P L_{\text {percentage }_{b, t}}+\alpha_{10} T D_{b, t} * N P L_{\text {percentage }_{b, t}}{ }^{2}+\varepsilon_{b, t}$

To investigate the effect of total diversification (TD) on ROA with multiplicative terms, the following regression is run.

$$
\begin{aligned}
& \text { ROA }_{b, t}=\alpha_{0}+\alpha_{1} T D_{b, t}+\alpha_{2} \text { Size }_{b, t}+\alpha_{3} \text { Own }_{1}+\alpha_{4} \text { Own }_{2}+\alpha_{5} D_{\text {time }}+ \\
& \alpha_{6} \text { Total Loans } \text { Total Assets }_{b, t}+\alpha_{7} \text { Growth }_{b, t}+\alpha_{8} \text { Interest }_{b, t}+\alpha_{9} \text { TD }_{b, t} * \\
& \text { NPL }_{\text {percentage }_{b, t}}+\alpha_{10} \text { TD }_{b, t} * N P L_{\text {percentage }_{b, t}}{ }^{2}+\varepsilon_{b, t}
\end{aligned}
$$

Finally, the influence of diversification on bank's risk is examined through the risk regression reported below.

$$
\begin{aligned}
& \text { InNPL }_{b, t}=\alpha_{0}+\alpha_{1} \text { AGD }_{b, t}+\alpha_{2} \text { TWGD }_{b, t}+\alpha_{3} \text { Size }_{b, t}+\alpha_{4} \text { Own }_{1}+\alpha_{5} \text { Own }_{2}+ \\
& \alpha_{6} D_{\text {time }}+\alpha_{7} \text { Total Loans } /_{\text {Total Assets }}+t \\
& \alpha_{10} \text { ROA }_{b, t-1}+\alpha_{8, t} \text { Growth }_{b, t}+\alpha_{9} \text { Interest }_{b, t}+
\end{aligned}
$$


To measure the effect of total diversification (TD) on banks' risk, the following regression is used.

$\operatorname{InNPL}_{b, t}=\alpha_{0}+\alpha_{1} T D_{b, t}+\alpha_{2}$ Size $_{b, t}+\alpha_{3} O w n_{1}+\alpha_{4} O w n_{2}+\alpha_{5} D_{\text {time }}+$ $\alpha_{6}$ Total Loans $_{\text {Total Assets }_{b, t}}+\alpha_{7}$ Growth $_{b, t}+\alpha_{8}$ Interest $_{b, t}+\alpha_{9}$ ROA $_{b, t-1}+$ $\varepsilon_{b, t}$

In all of the specifications above, $t$ represents the time period, while $b$ reflects banks.

\section{Findings}

In this section, first, the recent trends in the several diversification measures will be discussed. Next, the results of the above mentioned regression specifications for each product, loan and income diversification measure are reported in turn.

\subsection{Trends in Diversification and Other Variables}

In order to analyze the trends of total diversification measures, Figure 1 and Figure 2 are prepared. For the comparison, all the diversification measures are normalized by dividing them to $\ln (m)$, where $m$ stands for the number of components, e.g. loan types in a group.

Figure 1. Across Groups (AG) Diversification Trends 


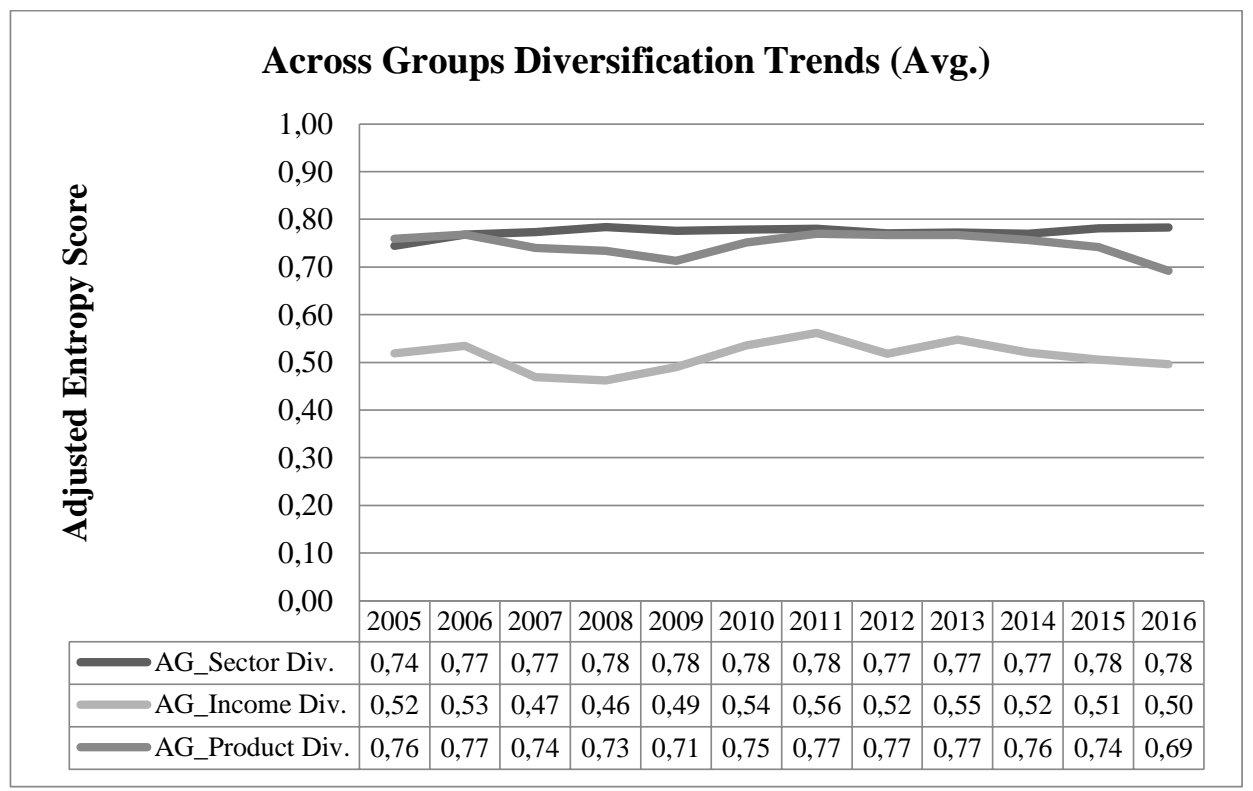

Figure 2. Total Within Group (WG) Diversification Trends

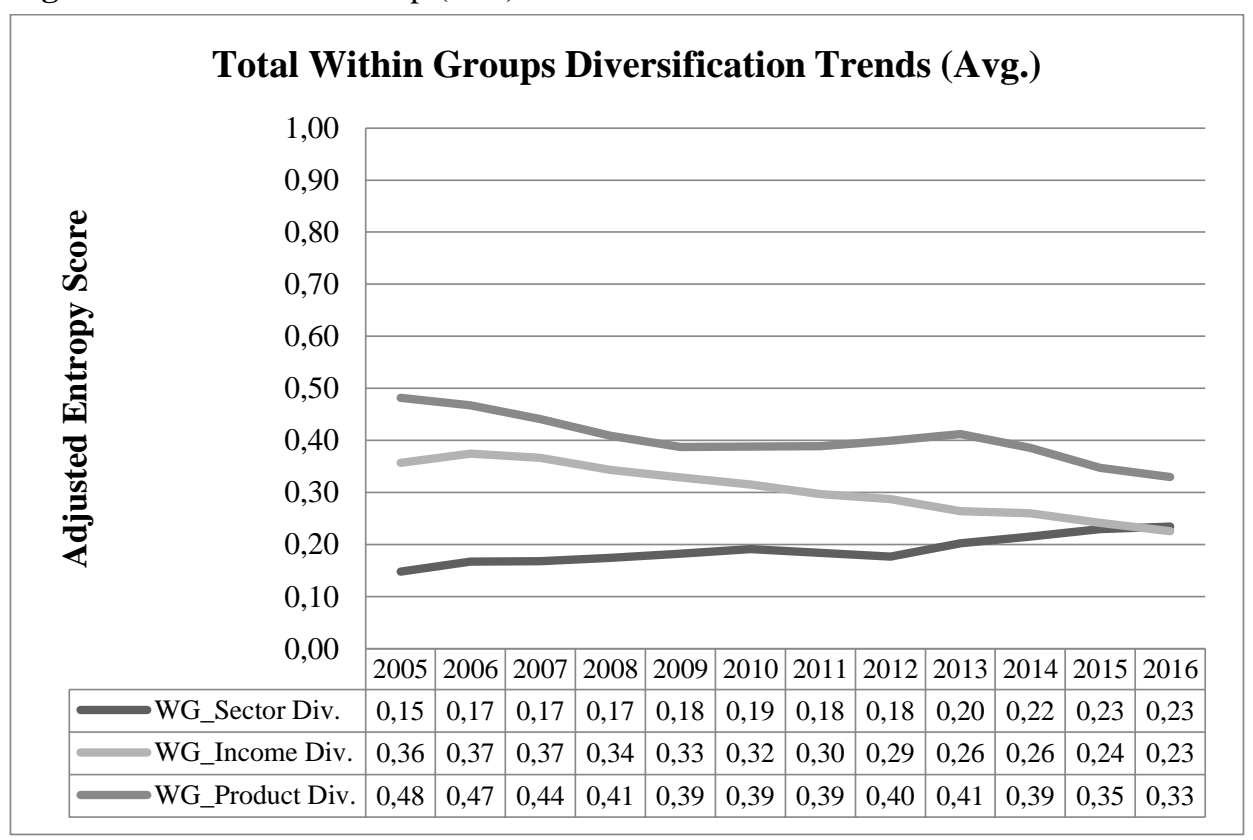


Above figures show that the income diversification is more focused than product diversification. Also, both diversification measures decreases as the time period comes close to 2016. This shows that, for income diversification, proportion of either interest or non-interest income increased during the time period. On the other hand, sector diversification has an increase in time.

Figure 3. Total diversification trends

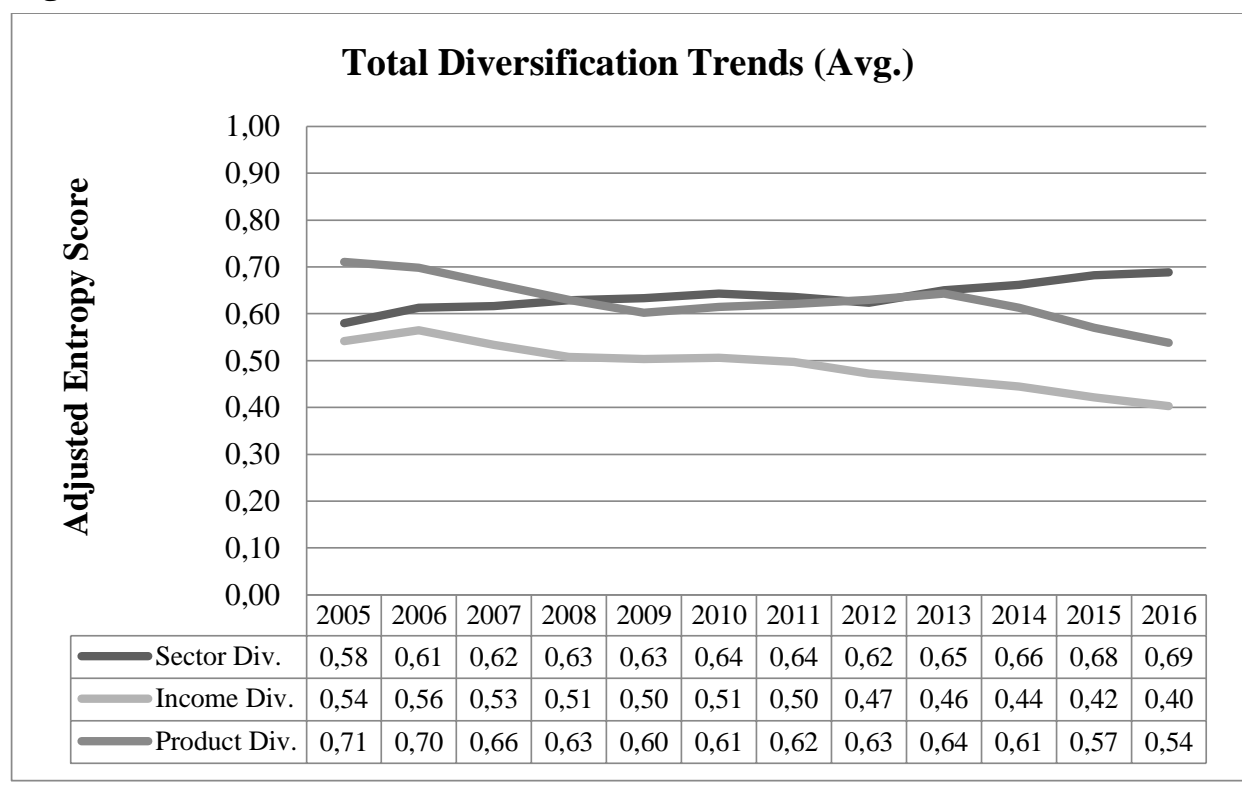

Figure 3 shows the overall downward trend of income and product diversification. It is interesting to note that between 2008 and 2011 income diversification and in the 2009-2013 period product diversification was relatively stable. On the contrary, sector diversification increased in the study period. These figures also show that the addition of trends in across groups and within groups diversification are in line with the trends in total diversification measure. Therefore, by using all these diversification measures in this study, the changes in total diversification measure can be traced back to its components and better analyzed. Given the relatively constant trend in across groups diversification, it is clear that the downward trend in total diversification is a result of effects of within groups diversification measure.

The graphs of variables used in the regressions are given below. 
Figure 4. Trends of Total Assets, Total Loans (Average) in millions TL and Interest

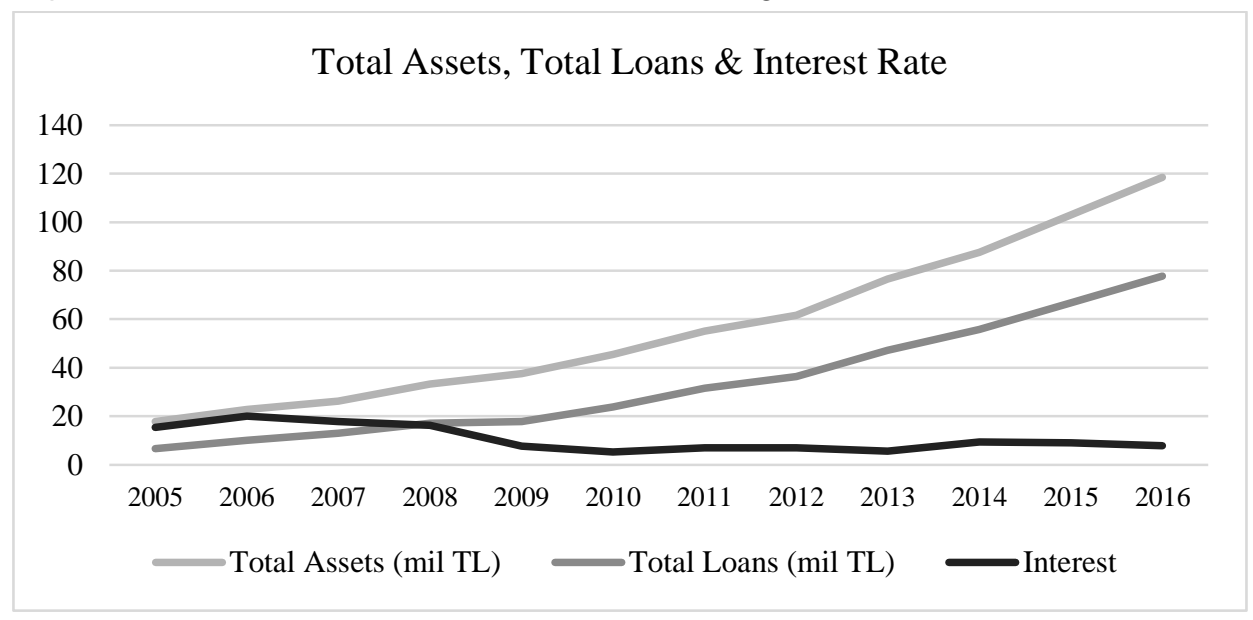

Here, we can see that total assets have an upward trend while interest rate has a downward trend in the analysis period. Upward trend in these variables means that the Turkish banking system expanded during the analysis period, especially after 2012. However, it also increased its risk in terms of nonperforming loans which can be observed below in Figure 6 .

Figure 5. Trends in ROA (Average)

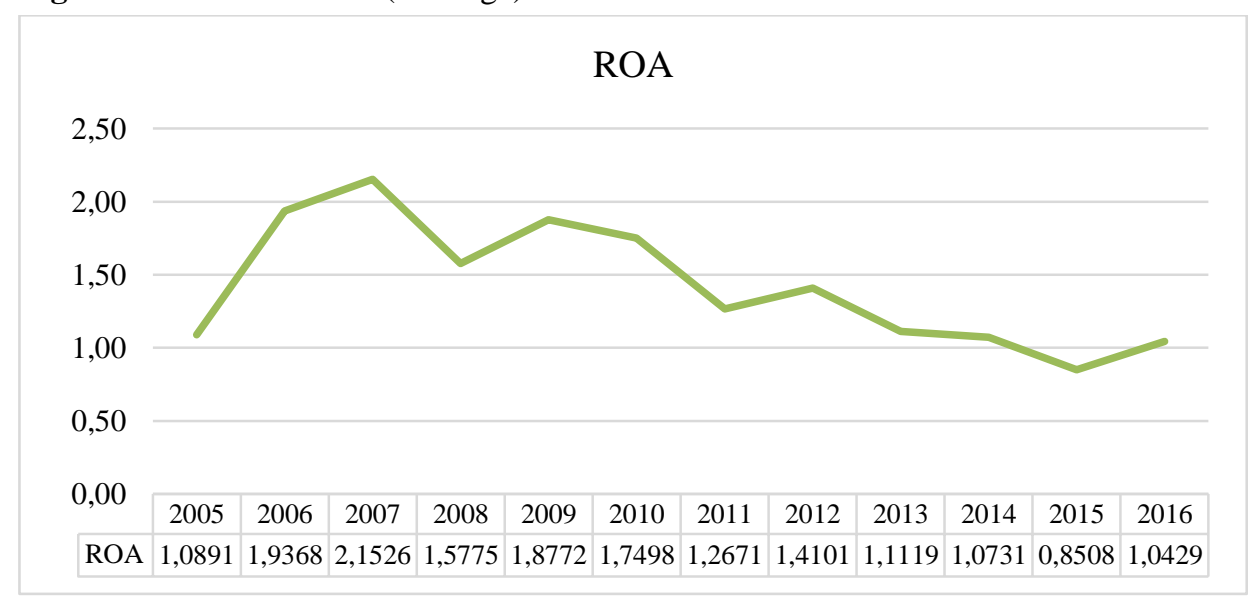

In Figure 5, we see a general downward trend in ROA with a small increase in 2016. Especially in 2008, 2011 and 2015, ROA was smaller than a year before and after. 
Figure 6. Trends in NPL/TA (Average)

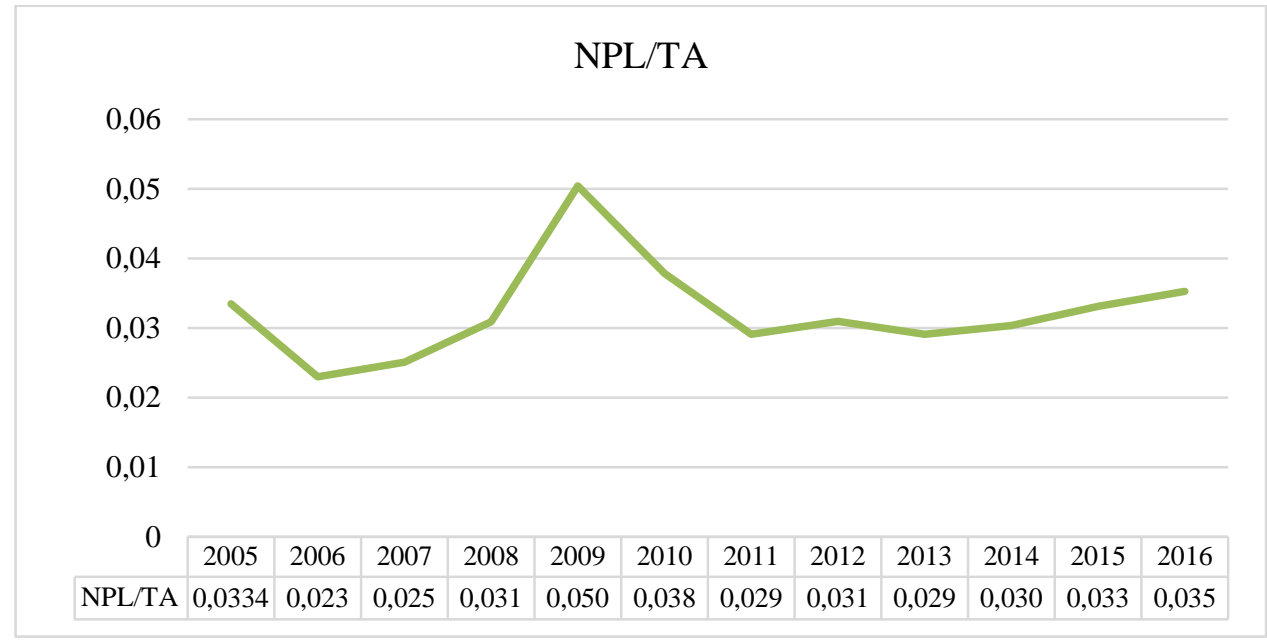

In Figure 6, we see a subtle increase in Nonperforming Loans/Total Assets in the study period. This means that the banks in Turkish banking system increased their risks. We also observe a peak during 2008-2009. To measure the effects of that peak, we included a time dummy in the analysis.

\subsection{Bank Return - Diversification Relationship}

In this section, we will explain the effects of different diversification measures, such as product, sector and income diversification types on the bank returns. Each type of diversification is decomposed using entropy measures in their within and across groups components, and each will be explained in turn. In addition, the possible nonlinearities in this relation are taken into account by employing the nonlinear model as explained in the previous sections.

\section{The Effects of Diversification on Bank Returns}

As mentioned before, to observe the impact of diversification for different diversification groupings, this paper employs a panel regression specification. First of all, all the regression assumptions are checked. No omitted variable problem is observed. Normal distribution of the error terms assumption is not satisfied. However, since the number of observations is large enough for the central limit theorem, the main implications of the model will not be changed in a considerable way. In addition, Citibank has missing values that do not allow us to compute the entropy measures for product diversification. Therefore, the analyses are conducted for 19 banks. Similarly, 
since Turkishbank and Turklandbank have missing values, they are dropped from sector diversification analyses.

The variance of error terms is not constant, therefore, there is a heteroscedasticity problem. As mentioned before, to correct this problem we employ the White estimator. For income diversification, no bank is needed to be removed from the dataset because of the missing value problem. The results from the Eq. (7) and (8) for the product, sector and income diversification for time $t$ can be seen in Table 5 .

Table 5. The Effect of Income and Product Diversification Measures on ROA

(TD: Total Diversification; TWG-AG: Total Within Groups \& Across Groups Models)

\begin{tabular}{|c|c|c|c|c|c|c|}
\hline & \multicolumn{6}{|c|}{ ROA } \\
\hline & $\begin{array}{c}\text { Income } \\
\text { TD } \\
\text { Model }\end{array}$ & $\begin{array}{c}\text { Income } \\
\text { TWG - AG } \\
\text { Model }\end{array}$ & $\begin{array}{l}\text { Product } \\
\text { TD Model }\end{array}$ & $\begin{array}{l}\text { Product } \\
\text { TWG - AG } \\
\text { Model }\end{array}$ & $\begin{array}{l}\text { Sector } \\
\text { TD } \\
\text { Model }\end{array}$ & $\begin{array}{c}\text { Sector } \\
\text { TWG - AG } \\
\text { Model }\end{array}$ \\
\hline Size & $\begin{array}{l}0.2128^{*} \\
(0.0002)\end{array}$ & $\begin{array}{l}0.2615^{*} \\
(0.0000)\end{array}$ & $\begin{array}{l}0.1832 * \\
(0.0136)\end{array}$ & $\begin{array}{c}0.1449 * * \\
(0.0365)\end{array}$ & $\begin{array}{c}0.1175^{* * *} \\
(0.0410)\end{array}$ & $\begin{array}{c}0.1350 * * \\
(0.0335)\end{array}$ \\
\hline $\begin{array}{l}\text { Ownership } \\
\text { Dummy } 1\end{array}$ & $\begin{array}{l}-0.1088 \\
(0.5699)\end{array}$ & $\begin{array}{c}-0.2219 * * * \\
(0.0920)\end{array}$ & $\begin{array}{l}-0.0001 \\
(0.9995)\end{array}$ & $\begin{array}{l}-0.0398 \\
(0.8223)\end{array}$ & $\begin{array}{l}-0.3112 \\
(0.1932)\end{array}$ & $\begin{array}{l}-0.4303 \\
(0.1239)\end{array}$ \\
\hline $\begin{array}{l}\text { Ownership } \\
\text { Dummy } 2\end{array}$ & $\begin{array}{c}0.2029 \\
(0.2563)\end{array}$ & $\begin{array}{c}0.1865 \\
(0.3288)\end{array}$ & $\begin{array}{c}0.3361 * * \\
(0.0438)\end{array}$ & $\begin{array}{l}0.4468^{*} \\
(0.0106)\end{array}$ & $\begin{array}{c}0.3924 \\
(0.1670)\end{array}$ & $\begin{array}{c}0.3934 \\
(0.1723)\end{array}$ \\
\hline Time Dummy & $\begin{array}{c}0.2419 \\
(0.3465)\end{array}$ & $\begin{array}{c}0.2140 \\
(0.4252)\end{array}$ & $\begin{array}{c}0.2879 \\
(0.2364)\end{array}$ & $\begin{array}{c}0.2618 \\
(0.1958)\end{array}$ & $\begin{array}{c}0.1844 \\
(0.4681)\end{array}$ & $\begin{array}{c}0.1541 \\
(0.5376)\end{array}$ \\
\hline Interest & $\begin{array}{l}0.0595^{*} \\
(0.0103)\end{array}$ & $\begin{array}{l}0.0597 * \\
(0.0115)\end{array}$ & $\begin{array}{c}0.0529 * * \\
(0.0373)\end{array}$ & $\begin{array}{c}0.0382 \\
(0.1529)\end{array}$ & $\begin{array}{c}0.0498 * * \\
(0.0413)\end{array}$ & $\begin{array}{c}0.0452 * * * \\
(0.0706)\end{array}$ \\
\hline $\begin{array}{l}\text { Total } \\
\text { Loans/Total } \\
\text { Assets }\end{array}$ & $\begin{array}{c}0.1485 \\
(0.1440)\end{array}$ & $\begin{array}{c}0.1431 \\
(0.1683)\end{array}$ & $\begin{array}{c}0.1629 \\
(0.1856)\end{array}$ & $\begin{array}{c}0.0480 \\
(0.5723)\end{array}$ & $\begin{array}{c}0.0893 \\
(0.4900)\end{array}$ & $\begin{array}{c}0.1492 \\
(0.3427)\end{array}$ \\
\hline Growth & $\begin{array}{l}-0.8491 \\
(0.1255)\end{array}$ & $\begin{array}{l}-0.8664 \\
(0.1322)\end{array}$ & $\begin{array}{l}-1.2847 \\
(0.2890)\end{array}$ & $\begin{array}{l}-1.3109 \\
(0.2820)\end{array}$ & $\begin{array}{l}-1.1011 \\
(0.0775)\end{array}$ & $\begin{array}{c}-1.0605 * * * \\
(0.0942)\end{array}$ \\
\hline $\begin{array}{l}\text { Total } \\
\text { Diversification }\end{array}$ & $\begin{array}{c}0.4820 \\
(0.2252)\end{array}$ & & $\begin{array}{c}0.5089 * * * \\
(0.0880)\end{array}$ & & $\begin{array}{l}-1.0019 * \\
(0.0023)\end{array}$ & \\
\hline $\begin{array}{l}\text { Across Groups } \\
\text { Diversification } \\
\text { (AGD) }\end{array}$ & & $\begin{array}{c}-0.5124 \\
(0.7077)\end{array}$ & & $\begin{array}{l}-0.5865 \\
(0.1603)\end{array}$ & & $\begin{array}{c}0.1546 \\
(0.7397)\end{array}$ \\
\hline $\begin{array}{l}\text { Total Within } \\
\text { Groups } \\
\text { Diversification } \\
\text { (TWGD) }\end{array}$ & & $\begin{array}{c}0.6845 * * \\
(0.0578)\end{array}$ & & $\begin{array}{l}1.1207 * \\
(0.0023)\end{array}$ & & $\begin{array}{l}-2.0112^{*} \\
(0.0085)\end{array}$ \\
\hline
\end{tabular}

$\mathrm{p}$ values in parantheses

$* * * \mathrm{p}<0.1, * * \mathrm{p}<0.05, * \mathrm{p}<0.01$ 
As seen from Table 5, total diversification in terms of banking products has a positive impact on the return on assets of Turkish banking industry. In fact, this positive effect is a result of total within diversification, which is a part of total diversification. Sector diversification, on the other hand, has a negative impact on profitability. Since ROA, income and product diversification are decreasing and sector diversification is increasing in the analysis period, these results are coherent.

Size is positive and significant in all of the models which means that bigger banks have higher profitability in Turkish Banking System. Also, in income diversification model, one of the ownership dummies is significant meaning that state owned banks have lower ROAs. Moreover, in product diversification models, it is observed that Turkish banks have higher performance in terms of profitability. Interest rate is significant in most of the models which is expected. Time dummy is insignificant in all models indicating that there are significant changes in ROA between 2008 and 2009. Total loans and growth are mostly insignificant.

In these models, product and sector total diversification measures are significant. The source of these significance can be traced back to its components, in this case total within groups diversification.

As explained before, the product and income diversification can also be discussed in detail as a function of risk in the nonlinear model. Results of this model are given in Table 6 .

Table 6. Product, Sector and Income Diversification on ROA (Multiplicative Model)

(TD: Total Diversification; TWG-AG: Total Within Groups \& Across Groups Models)

\begin{tabular}{|l|c|c|c|c|c|c|}
\hline \multirow{1}{*}{} & \multicolumn{7}{|c|}{ ROA (Multiplicative) } \\
\cline { 2 - 7 } & $\begin{array}{c}\text { Income } \\
\text { TD } \\
\text { Model }\end{array}$ & $\begin{array}{c}\text { Income } \\
\text { TWG - AG } \\
\text { Model }\end{array}$ & $\begin{array}{c}\text { Product } \\
\text { TD Model }\end{array}$ & $\begin{array}{c}\text { Product } \\
\text { TWG - AG } \\
\text { Model }\end{array}$ & $\begin{array}{c}\text { Sector } \\
\text { TD Model }\end{array}$ & $\begin{array}{c}\text { Sector } \\
\text { TWG - AG } \\
\text { Model }\end{array}$ \\
\hline Size & $\begin{array}{c}0.1906^{*} \\
(0.0052)\end{array}$ & $\begin{array}{c}0.2079^{*} \\
(0.0000)\end{array}$ & $\begin{array}{c}0.1772 * * \\
(0.0308)\end{array}$ & $\begin{array}{c}0.1315^{* * *} \\
(0.0838)\end{array}$ & $\begin{array}{c}0.0478 \\
(0.5608)\end{array}$ & $\begin{array}{c}0.0642 \\
(0.4705)\end{array}$ \\
\hline Ownership & 0.2424 & 0.1924 & 0.2494 & 0.2306 & 0.0653 & -0.0457 \\
Dummy 1 & $(0.3504)$ & $(0.2280)$ & $(0.3225)$ & $(0.3533)$ & $(0.8243)$ & $(0.8957)$ \\
\hline Ownership & 0.0089 & 0.0098 & 0.2212 & $0.3418^{* * *}$ & 0.2145 & 0.2203 \\
Dummy 2 & $(0.9688)$ & $(0.9650)$ & $(0.2501)$ & $(0.1068)$ & $(0.4901)$ & $(0.4929)$ \\
\hline
\end{tabular}


- Ankara Üniversitesi SBF Dergisi • 73 (4)

\begin{tabular}{|c|c|c|c|c|c|c|}
\hline Time Dummy & $\begin{array}{c}0.3517 \\
(0.2685)\end{array}$ & $\begin{array}{c}0.3384 \\
(0.2859)\end{array}$ & $\begin{array}{c}0.3457 \\
(0.2332)\end{array}$ & $\begin{array}{c}0.3012 \\
(0.2204)\end{array}$ & $\begin{array}{c}0.3417 \\
(0.3062)\end{array}$ & $\begin{array}{c}0.3128 \\
(0.3467)\end{array}$ \\
\hline Interest & $\begin{array}{c}0.0499 * * \\
(0.0434)\end{array}$ & $\begin{array}{c}0.0503 * * \\
(0.0445)\end{array}$ & $\begin{array}{c}0.0508 * * \\
(0.0528)\end{array}$ & $\begin{array}{c}0.0341 \\
(0.2038)\end{array}$ & $\begin{array}{c}0.0360 \\
(0.1874)\end{array}$ & $\begin{array}{c}0.0324 \\
(0.2351)\end{array}$ \\
\hline $\begin{array}{l}\text { Total } \\
\text { Loans/Total } \\
\text { Assets }\end{array}$ & $\begin{array}{c}0.0720 \\
(0.4927)\end{array}$ & $\begin{array}{c}0.0729 \\
(0.4900)\end{array}$ & $\begin{array}{c}0.1056 \\
(0.4236)\end{array}$ & $\begin{array}{l}-0.0291 \\
(0.7814)\end{array}$ & $\begin{array}{l}-0.0737 \\
(0.5663)\end{array}$ & $\begin{array}{l}-0.0193 \\
(0.8998)\end{array}$ \\
\hline Growth & $\begin{array}{c}-0.8497 * * * \\
(0.0998)\end{array}$ & $\begin{array}{l}-0.8555 \\
(0.1103)\end{array}$ & $\begin{array}{l}-1.2808 \\
(0.2842)\end{array}$ & $\begin{array}{l}-1.3119 \\
(0.2757)\end{array}$ & $\begin{array}{c}-1.1355^{* * * *} \\
(0.0663)\end{array}$ & $\begin{array}{c}-1.1005^{\text {**** }} \\
(0.0799)\end{array}$ \\
\hline $\begin{array}{l}\text { Total } \\
\text { Diversification } \\
\text { * NPL } \\
\text { Percentage }\end{array}$ & $\begin{array}{l}-7.5641 \\
(0.3763)\end{array}$ & $\begin{array}{l}-7.2955 \\
(0.3593)\end{array}$ & $\begin{array}{l}-3.3849 \\
(0.5617)\end{array}$ & $\begin{array}{l}-2.2949 \\
(0.6988)\end{array}$ & $\begin{array}{c}-8.0948 * * * \\
(0.0851)\end{array}$ & $\begin{array}{c}-7.9380 \text { *** } \\
(0.0992)\end{array}$ \\
\hline $\begin{array}{l}\text { Total } \\
\text { Diversification } \\
\text { * NPL } \\
\text { Percentage }^{2} \\
\end{array}$ & $\begin{array}{l}-0.2507 \\
(0.9934)\end{array}$ & $\begin{array}{l}-0.3337 \\
(0.9912)\end{array}$ & $\begin{array}{l}-2.7508 \\
(0.9025)\end{array}$ & $\begin{array}{l}-9.4860 \\
(0.6613)\end{array}$ & $\begin{array}{l}10.5534 \\
(0.4666)\end{array}$ & $\begin{array}{l}10.5314 \\
(0.4716)\end{array}$ \\
\hline $\begin{array}{l}\text { Total } \\
\text { Diversification }\end{array}$ & $\begin{array}{c}0.9863 * * \\
(0.0334)\end{array}$ & & $\begin{array}{c}0.5964 \\
(0.1796)\end{array}$ & & $\begin{array}{c}-0.7481 * * * \\
(0.0753)\end{array}$ & \\
\hline $\begin{array}{l}\text { Across Groups } \\
\text { Diversification }\end{array}$ & & $\begin{array}{c}0.6295 \\
(0.5292)\end{array}$ & & $\begin{array}{l}-0.7297 \\
(0.1787)\end{array}$ & & $\begin{array}{c}0.2225 \\
(0.5468)\end{array}$ \\
\hline $\begin{array}{l}\text { Total Within } \\
\text { Groups } \\
\text { Diversification }\end{array}$ & & $\begin{array}{c}1.0372 * * \\
(0.0400)\end{array}$ & & $\begin{array}{l}1.2940 * \\
(0.0050)\end{array}$ & & $\begin{array}{c}-1.6061 * * \\
(0.0567)\end{array}$ \\
\hline
\end{tabular}

$\mathrm{p}$ values in parantheses

$* * * \mathrm{p}<0.1, * * \mathrm{p}<0.05, * \mathrm{p}<0.01$

Again, the size of the banks is significant in product and income diversification models. In one of the product diversification models, the Turkish banks are found more profitable indicated by the positive and significant coefficient of the ownership dummy 2. As expected, time dummy is insignificant in all models which means that there is no crisis observed in ROA between 2008 and 2009. The growth of total assets has a negative and significant impact on ROA in the analysis period. Multiplicative terms are insignificant in most of the models.

Similar to the ROA models above, income and product diversification have a positive impact on ROA and sector diversification has a negative and 
significant effect. When we trace the significance of total diversification, we find that total within groups diversification is significant.

Table 7. Product, Sector and Income Diversification on RISK

(TD: Total Diversification; TWG-AG: Total Within Groups \& Across Groups Models)

\begin{tabular}{|c|c|c|c|c|c|c|}
\hline & \multicolumn{6}{|c|}{ In NPL } \\
\hline & $\begin{array}{c}\text { Income } \\
\text { TD } \\
\text { Model }\end{array}$ & $\begin{array}{c}\text { Income } \\
\text { TWG - AG } \\
\text { Model }\end{array}$ & $\begin{array}{c}\text { Product } \\
\text { TD Model }\end{array}$ & $\begin{array}{c}\text { Product } \\
\text { TWG - AG } \\
\text { Model }\end{array}$ & $\begin{array}{c}\text { Sector } \\
\text { TD Model }\end{array}$ & $\begin{array}{c}\text { Sector } \\
\text { TWG - AG } \\
\text { Model }\end{array}$ \\
\hline Size & $\begin{array}{l}1.0144 * \\
(0.0000)\end{array}$ & $\begin{array}{l}0.9703^{*} \\
(0.0000)\end{array}$ & $\begin{array}{l}1.0560 * \\
(0.0000)\end{array}$ & $\begin{array}{l}1.0786^{*} \\
(0.0000)\end{array}$ & $\begin{array}{l}0.8977 * \\
(0.0000)\end{array}$ & $\begin{array}{l}0.8890 * \\
(0.0000)\end{array}$ \\
\hline $\begin{array}{l}\text { Ownership } \\
\text { Dummy } 1\end{array}$ & $\begin{array}{l}-0.0890 \\
(0.1184)\end{array}$ & $\begin{array}{c}0.0083 \\
(0.9197)\end{array}$ & $\begin{array}{c}-0.1575^{*} \\
(0.0023)\end{array}$ & $\begin{array}{c}-0.1487 * \\
(0.0090)\end{array}$ & $\begin{array}{c}0.0350 \\
(0.6306)\end{array}$ & $\begin{array}{c}0.0887 * * * \\
(0.0964)\end{array}$ \\
\hline $\begin{array}{l}\text { Ownership } \\
\text { Dummy } 2\end{array}$ & $\begin{array}{c}-0.2499 * \\
(0.0000)\end{array}$ & $\begin{array}{c}-0.2299 * \\
(0.0000)\end{array}$ & $\begin{array}{c}-0.2239 \\
*(0.0000)\end{array}$ & $\begin{array}{c}-0.2899 * \\
(0.0000)\end{array}$ & $\begin{array}{c}-0.2079 * \\
(0.0002)\end{array}$ & $\begin{array}{c}-0.2135 * \\
(0.0001)\end{array}$ \\
\hline ROA t-1 & $\begin{array}{c}0.0464 * * * \\
(0.1036)\end{array}$ & $\begin{array}{c}-0.0442 * * * \\
(0.0808)\end{array}$ & $\begin{array}{c}0.8524 * * \\
(0.0527)\end{array}$ & $\begin{array}{l}-0.0410 \\
(0.2152)\end{array}$ & $\begin{array}{c}-0.0749 * \\
(0.0000)\end{array}$ & $\begin{array}{c}-0.0704 * \\
(0.0001)\end{array}$ \\
\hline Time Dummy & $\begin{array}{l}0.4330^{*} \\
(0.0000)\end{array}$ & $\begin{array}{l}0.4494^{*} \\
(0.0000)\end{array}$ & $\begin{array}{l}0.3789 * \\
(0.0000)\end{array}$ & $\begin{array}{l}0.4003 * \\
(0.0000)\end{array}$ & $\begin{array}{l}0.3585^{*} \\
(0.0000)\end{array}$ & $\begin{array}{l}0.3708 * \\
(0.0000)\end{array}$ \\
\hline $\begin{array}{l}\text { Total } \\
\text { Loans/Total } \\
\text { Assets }\end{array}$ & $\begin{array}{l}0.2788^{*} \\
(0.0000)\end{array}$ & $\begin{array}{l}0.2806 * \\
(0.0000)\end{array}$ & $\begin{array}{l}0.2895 * \\
(0.0001)\end{array}$ & $\begin{array}{l}0.3516^{*} \\
(0.0004)\end{array}$ & $\begin{array}{l}0.2450 * \\
(0.0000)\end{array}$ & $\begin{array}{l}0.2209 * \\
(0.0000)\end{array}$ \\
\hline Growth & $\begin{array}{l}-0.1775 \\
(0.2011)\end{array}$ & $\begin{array}{l}-0.1682 \\
(0.2226)\end{array}$ & $\begin{array}{l}-0.2023 \\
(0.3103)\end{array}$ & $\begin{array}{l}-0.1788 \\
(0.3840)\end{array}$ & $\begin{array}{c}-0.2324 * * \\
(0.0267)\end{array}$ & $\begin{array}{c}-0.2463 * * \\
(0.0381)\end{array}$ \\
\hline Interest & $\begin{array}{c}-0.0258^{*} \\
(0.0104)\end{array}$ & $\begin{array}{c}-0.0255^{*} \\
(0.0083)\end{array}$ & $\begin{array}{c}-0.0262 * \\
(0.0018)\end{array}$ & $\begin{array}{c}-0.0196 * * \\
(0.0429)\end{array}$ & $\begin{array}{c}-0.0330 * \\
(0.0000)\end{array}$ & $\begin{array}{c}-0.0314 * \\
(0.0000)\end{array}$ \\
\hline $\begin{array}{l}\text { Total } \\
\text { Diversification }\end{array}$ & $\begin{array}{c}-0.5966^{*} \\
(0.0001)\end{array}$ & & $\begin{array}{c}-0.3223 * \\
(0.0002)\end{array}$ & & $\begin{array}{c}0.1330 \\
(0.3554)\end{array}$ & \\
\hline $\begin{array}{l}\text { Across Groups } \\
\text { Diversification }\end{array}$ & & $\begin{array}{c}0.2693 \\
(0.3880)\end{array}$ & & $\begin{array}{c}0.2488 \\
(0.2774)\end{array}$ & & $\begin{array}{l}-0.3356 \\
(0.2731)\end{array}$ \\
\hline $\begin{array}{l}\text { Total Within } \\
\text { Groups } \\
\text { Diversification }\end{array}$ & & $\begin{array}{c}-0.7715^{*} \\
(0.0000)\end{array}$ & & $\begin{array}{c}-0.6605 \\
(0.0000)^{*}\end{array}$ & & $\begin{array}{l}0.5605 * \\
(0.0001)\end{array}$ \\
\hline
\end{tabular}

$\mathrm{p}$ values in parantheses

$* * * \mathrm{p}<0.1, * * \mathrm{p}<0.05, * \mathrm{p}<0.01$

Lastly, when we look at the risk models, we observe the opposite results from the ROA models. Product and income diversification have a negative impact on risk, whereas sector diversification increases banks' risk. Time dummy is significant in this case, which can be observed from the NPL/TA 
graph. Also, interest rate has a negative effect on risk. As expected, banks' risk attitude measured by Total Loans/Total Assets has a positive and significant coefficient. Growth and lagged ROA have a negative and significant relationship with risk in many of the models. Also, Turkish banks are observed to have smaller NPL whereas bigger banks have high NPL. in Table 8.

For the sake of simplicity all the results explained above are summarized

Table 8. Summary of the Results

\begin{tabular}{|l|c|c|c|}
\cline { 2 - 4 } \multicolumn{1}{c|}{} & \multicolumn{3}{c|}{ Dependent Variables } \\
\hline Diversification Component & ROA & ROA (Multiplicative) & RISK \\
\hline AGD-Income & N/Sig & N/Sig & N/Sig \\
\hline TWGD-Income & $(+)$ & $(+)$ & $(-)$ \\
\hline AGD-Product & N/Sig & N/Sig & N/Sig \\
\hline TWGD-Product & $(+)$ & $(+)$ & $(-)$ \\
\hline AGD-Sector & N/Sig & N/Sig & N/Sig \\
\hline TWGD-Sector & $(-)$ & $(-)$ & $(+)$ \\
\hline TD-Income & N/Sig & $(+)$ & $(-)$ \\
\hline TD-Product & $(+)$ & N/Sig & $(-)$ \\
\hline TD-Sector & $(-)$ & $(-)$ & N/Sig \\
\hline
\end{tabular}

\section{Conclusion}

After the year 2003, the performance of Turkish Banking Sector generally improved over time in terms of healthiness measures, i.e. CAMEL indicators which consists of the weighted average of returns, loan risk, capital adequacy, asset quality and liquidity measures altogether; the profit rates (margins) of the Turkish banking sector decreased due to the more competitive environment and the effects of global crises. Then, diversification decisions become more crucial in bank management strategies.

In this context, the main hypothesis of the paper was the banks that have a higher degree of loan and/or income diversification are the ones that have higher performance, i.e. they are more profitable and less risky because they benefitted from some of the measures (or types/components) of diversification. In order to analyze the costs and benefits of diversification for banks panel data 
regressions are held between performance measures and diversification measures. When dealing with components separately, main research question of this study stated as follows: Is diversification mostly done within groups, i.e. related diversification or between groups, i.e. unrelated diversification more related with performance measures? Moreover, which component of total diversification and in which way does it affect the performance?

In order to answer these questions and test the hypothesis, the paper empirically analyzes the effects of loan and income diversification strategies on the performances of a selected sample of Turkish commercial banks over the period 2005-2016.

We found that the income and product (sector) diversification increase (decrease) the banks' performance, whereas income and product (sector) diversification decrease (increase) the banks' risk. These effects are mainly apparent for the within groups diversification, rather than the across groups.

In conclusion, the main results which are summarized in the previous section show that there is evidence in our study that diversification in terms of product and income increases ROA (profitability) and reduces NPL (risk). Moreover, it is shown in this study that when investigating the effects of diversification using many dimensions of this factor is more beneficial than using only total measures.

Repeating the analyses for the other dimensions of diversification (geographical and with respect to borrowers), in the future periods would be valuable extensions of this study.

\section{References}

Aleskerov, Fuad., Hasan Ersel and Mercan (2001), "Structural Dissimilarity in Turkish Banks 19881999", Bogazici Journal Review of Social Economic and Administrative Studies, 15 (1): 57-69.

Acharya, Viral V., Iftekhar Hasan and Anthony Saunders (2006), "Should Banks be Diversified? Evidence from Individual Bank Loan Portfolios”, Journal of Business, 79 (3): 1355-1412.

Baele, Lieven, Olivier De Jonghe, and Rudi Vander Vennet (2007), "Does the Stock Market Value Bank Diversification?", Journal of Banking \& Finance, 31 (7): 1999-2023.

Banking Regulation and Supervision Agency (2011), Turkish Banking Sector Main Indicators.

Banking Regulation and Supervision Agency (2010), Turkish Banking Sector Main Indicators.

Banks Association of Turkey (2017), Bankalarımız 2016 (İstanbul: TBB Yayın No:321).

Basel Banking Committee on Banking Supervision (2011), "Basel II: Revised International Capital Framework". 
Behr, Andreas, Andreas Kamp, Andreas Pfingsten and Christoph Memmel (2007), "Diversification and the Banks' Risk-Return Characteristics: Evidence from Loan Portfolios of German Banks", Working paper, Deutsche Bundesbank.

Berger, Allen N., Nathan Miller, Mitchell Petersen, Raghuram Rajan and Jeremy Stein (2001) "Does Function Follow Organizational Form? Evidence from the Lending Practices of Large and Small Banks" Working paper, University of Chicago.

Berger, Allen N., Iftekhar Hasan and Mingming Zhou (2010), "The Effects of Focus versus Diversification on Bank Performance: Evidence From Chinese Banks", Journal of Banking \& Finance, 34 (7): 1417-1435.

Berger, Philip G. and Eli Ofek (1995). "Diversification's Effect on Firm Value", Journal of Financial Economics, 37 (1): 39-65.

Campa, J.M., and S. Kedia (2002). "Explaining the Diversification Discount". Journal of Finance, 57, $1731-1762$

Cerasi, Vittoria and Sonja Daltung (2000), "The Optimal Size of A Bank: Costs and Benefits of Diversification", European Economic Review, 44 (9): 1701-1726.

Chiorazzo, Vincenzo, Carlo Milani and Francesca Salvini (2008), "Income Diversification and Bank Performance: Evidence from Italian Banks", Journal of Financial Services Research, 33 (3): 181-203.

Çınar, Yetkin (2011), "Efficiency Dynamics and Structural Characteristics of the Largest Commercial Banks in Turkey", Economic Journal Higher School of Economics, 15 (3): 315-335.

Denis, David J., Diane K. Denis and Atulya Sarin (1997), "Agency Problems, Equity Ownership and Corporate Diversification". Journal of Finance, 52 (1): 135-160.

Diamond, Douglas (1984), "Financial Intermediation and Delegated Monitoring", Review of Economic Studies, 51 (3): 393-414

Diamond, Douglas and Raghuram Rajan (2001), "Liquidity Risk, Liquidity Creation and Financial Fragility: A Theory of Banking", Journal of Political Economy, 109 (2): 287-327.

Elsas, Ralf, Andreas Hackethal and Markus Holzhäuser (2010) "The Anatomy of Bank Diversification." Journal of Banking \& Finance 34 (6): 1274-1287.

Gascón, Fernando and Victor González (2000), "Diversification, Size and Risk at Spanish Banks", Working Paper.

Graham, John R., Michael L. Lemmon, and Jack G. Wolf (2002), "Does Corporate Diversification Destroy Value?", Journal of Finance, 57 (2): 695-720.

Gurbuz, Ali Osman, Serhat Yanik, and Yusuf Ayturk (2013), "Income Diversification and Bank Performance: Evidence from Turkish Banking Sector", Journal of BRSA Banking and Financial Markets, 7 (1): 9-29.

Hayden, Evelyn, Daniel Porath and Natalja V. Westernhagen (2007). "Does Diversification Improve The Performance of German Banks? Evidence from Individual Bank Loan Portfolios", Journal of Financial Services Research, 32 (3): 123-140.

Jacquemin, Alexis P. and Charles H. Berry (1979), "Entropy Measure of Diversification and Corporate Growth", The Journal of Industrial Economics, 27 (4): 359-369.

Kaufman, George G. (1994), "Bank Contagion: A Review of Theory and Evidence", Journal of Financial Services Research, 8 (2): 123-150.

Lee, Bong Soo, and Ming-Yuan Leon Li (2012), "Diversification and Risk-Adjusted Performance: A Quantile Regression Approach", Journal of Banking \& Finance, 36 (7): 2157-2173. 
Lee, Chien-Chiang, Shih-Jui Yang, and Chi-Hung Chang (2014), "Non-Interest Income, Profitability, and Risk in Banking Industry: A Cross-Country Analysis", The North American Journal of Economics and Finance, 27: 48-67.

Mercieca, Steve, Klaus Schaeck, and Simon Wolfe (2007), "Small European Banks: Benefits From Diversification?", Journal of Banking and Finance, 31 (7): 1975-1998.

Meslier, Céline, Ruth Tacneng, and Amine Tarazi (2014), "Is bank income diversification beneficial? Evidence from an emerging economy", Journal of International Financial Markets, Institutions and Money, 31: 97-126.

Palepu, Krishna G. (1985), "Diversification Strategy, Profit Performance and the Entropy Measure", Strategic Management Journal, 6 (3): 239-255.

Rajan, Raghuram (1992), "Insiders and Outsiders: The Choice between Relationship and Arms Length Debt", Journal of Finance, 47 (4): 1367-1400.

Sawada, Michiru (2013), "How Does the Stock Market Value Bank Diversification? Empirical Evidence from Japanese Banks", Pacific-Basin Finance Journal, 25, 40-61.

Shannon, Claude E. (1948), "A Note on the Concept of Entropy", Bell System Tech. J, 27 (3): 379423.

Sharpe, Steven (1990), "Asymmetric Information, Bank Lending and Implicit Contracts: A Stylized Model of Customer Relationships", Journal of Finance, 45 (4): 1069-1087.

Stein, Jeremy (2002), "Information Production and Capital Allocation: Decentralized vs. Hierarchical Firms", Journal of Finance, 57 (5): 1891-1921.

Stiroh, Kevin J. (2002), "Diversification In Banking: Is Noninterest Income The Answer?" Working Paper, Federal Reserve Bank of New York.

Stiroh, Kevin J., and Adrienne Rumble (2006), "The Dark Side of Diversification: The Case of US Financial Holding Companies", Journal of Banking \& Finance, 30 (8): 2131-2161.

Vallascas, Francesco, Fabrizio Crespi, and Jens Hagendorff (2011), "Income Diversification and Bank Performance during the Financial Crisis", Working Paper

Villalonga, Belen (2004), "Diversification Discount or Premium? New Evidence from the Business Information Tracking Series", Journal of Finance, 59 (2): 479-506.

Winton, Andrew (1999), "Don't put all your eggs in one basket? Diversification and specialization in lending", Working paper, University of Minnesota.

Tabak, Benjamin M., Dimas M. Fazio, and Daniel O. Cajueiro (2011), "The Effects of Loan Portfolio Concentration on Brazilian Banks' Return and Risk", Journal of Banking \& Finance, 35 (11): 3065-3076.

Zhou, Kaiguo (2014), "The Effect of Income Diversification on Bank Risk: Evidence from China", Emerging Markets Finance and Trade, 50 (Sup3): 201-213. 


\section{Appendix}

Table A. Variable Definitions for Analyses:

\begin{tabular}{|c|c|c|}
\hline Variable & & Definition \\
\hline Dependent Variable & $\begin{array}{l}\text { Return on Assets } \\
\left(\operatorname{ROA}_{b, t}\right)\end{array}$ & $\begin{array}{l}\text { Natural Logarithm of Non- } \\
\text { Performing Loans of each bank } b \text { at } \\
\text { time } t \\
\text { Net Income /Total Assets of each } \\
\text { bank } b \text { at time } t\end{array}$ \\
\hline \multicolumn{3}{|l|}{ Independent Variables } \\
\hline & $\begin{array}{l}\text { Total Diversification } \\
\text { (TD) }\end{array}$ & Defined in Equation (2) \\
\hline \multirow[t]{2}{*}{ Diversification Measures } & $\begin{array}{l}\text { Total Within Group } \\
\text { Diversification (Related } \\
\text { Diversification - } \\
\text { TWGD) }\end{array}$ & Defined in Equation (4) \\
\hline & $\begin{array}{l}\text { Across Group } \\
\text { Diversification } \\
\text { (Unrelated } \\
\text { Diversification - AGD) }\end{array}$ & Defined in Equation (5) \\
\hline Ownership Dummies & $\begin{array}{l}\text { Ownership Dummy } 1_{\mathrm{t}} \\
\text { Ownership Dummy } 2 \mathrm{t}\end{array}$ & $\begin{array}{l}=\left\{\begin{array}{l}1 \text { if the bank is state }- \text { owned } \\
0 \text { if the bank is private }- \text { owned }\end{array}\right. \\
=\left\{\begin{array}{c}1 \text { if more than } 51 \% \text { of the shares } \\
\text { are held by Turkish investors }\end{array}\right.\end{array}$ \\
\hline \multirow[t]{2}{*}{ Macroeconomic Factors } & Time Dummy & $\begin{aligned} 0 & \text { if foreign held } \\
= & \left\{\begin{array}{l}1 \text { if year }=2008 \text { and } 2009 \\
0\end{array}\right.\end{aligned}$ \\
\hline & $\begin{array}{l}\text { Total Loans/Total } \\
\text { Assetsb,t } \\
\text { Interest }\end{array}$ & $\begin{array}{l}\text { Total Loans divided by Total Assets } \\
\text { of bank } b \text { at time } t \\
\text { Overnight interest rate at time } t\end{array}$ \\
\hline \multirow[t]{3}{*}{ Control Variables } & Sizeb,t & $\begin{array}{l}\text { Ln(Total Assets) of each bank } b \text { at } \\
\text { time } t \\
\text { Return on }\end{array}$ \\
\hline & $\mathrm{ROA}_{b, t-1}$ & $\begin{array}{l}\text { Net Income /Total Assets of each } \\
\text { bank } b \text { at time } t-1\end{array}$ \\
\hline & Growth $_{b, t}$ & $\begin{array}{l}\text { Annual Growth Rate of bank } b \text { at } \\
\text { time } t\end{array}$ \\
\hline \multirow[t]{4}{*}{ Risk Variables } & NPL_percentage $e_{b, t}$ & $\begin{array}{l}\text { Non-Performing Loans (NPL) /Total } \\
\text { Loans }\end{array}$ \\
\hline & NPL_percentage ${ }^{2}$ b,t & (NPL/Total Loans) $)^{2}$ \\
\hline & $\begin{array}{l}\mathrm{TD}_{\mathrm{b}, \mathrm{t}} \mathrm{x} \\
\text { NPL_percentage } \mathrm{b}, \mathrm{t}\end{array}$ & $\begin{array}{l}\text { Total Diversification of each bank } b \\
\text { at time } t \text { multiplied by NPL/Total } \\
\text { Loans }\end{array}$ \\
\hline & $\begin{array}{l}\mathrm{TD}_{\mathrm{b}, \mathrm{t}} \mathrm{x} \\
\text { NPL_percentage }_{\mathrm{b}, \mathrm{t}}\end{array}$ & $\begin{array}{l}\text { Total Diversification of each bank } b \\
\text { at time } t \text { multiplied by (NPL/Total } \\
\text { Loans) })^{2}\end{array}$ \\
\hline
\end{tabular}

